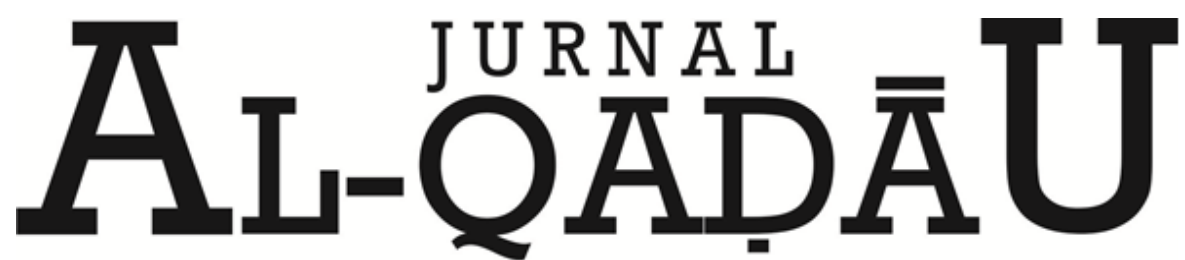

PERADILAN dan HUKUM KELUARGA ISLAM

\section{Fikih Etimologi Inna' wa Ahwātuhā dalam memahami Ayat-ayat Hukum}

Fiqh Etimology Inna 'wa Aḳwātuhā in Understanding the Law Verses

Supardin

Dosen Fakultas Syariah dan Hukum UIN Alauddin Makassar

Email: supardinpati@gmail.com

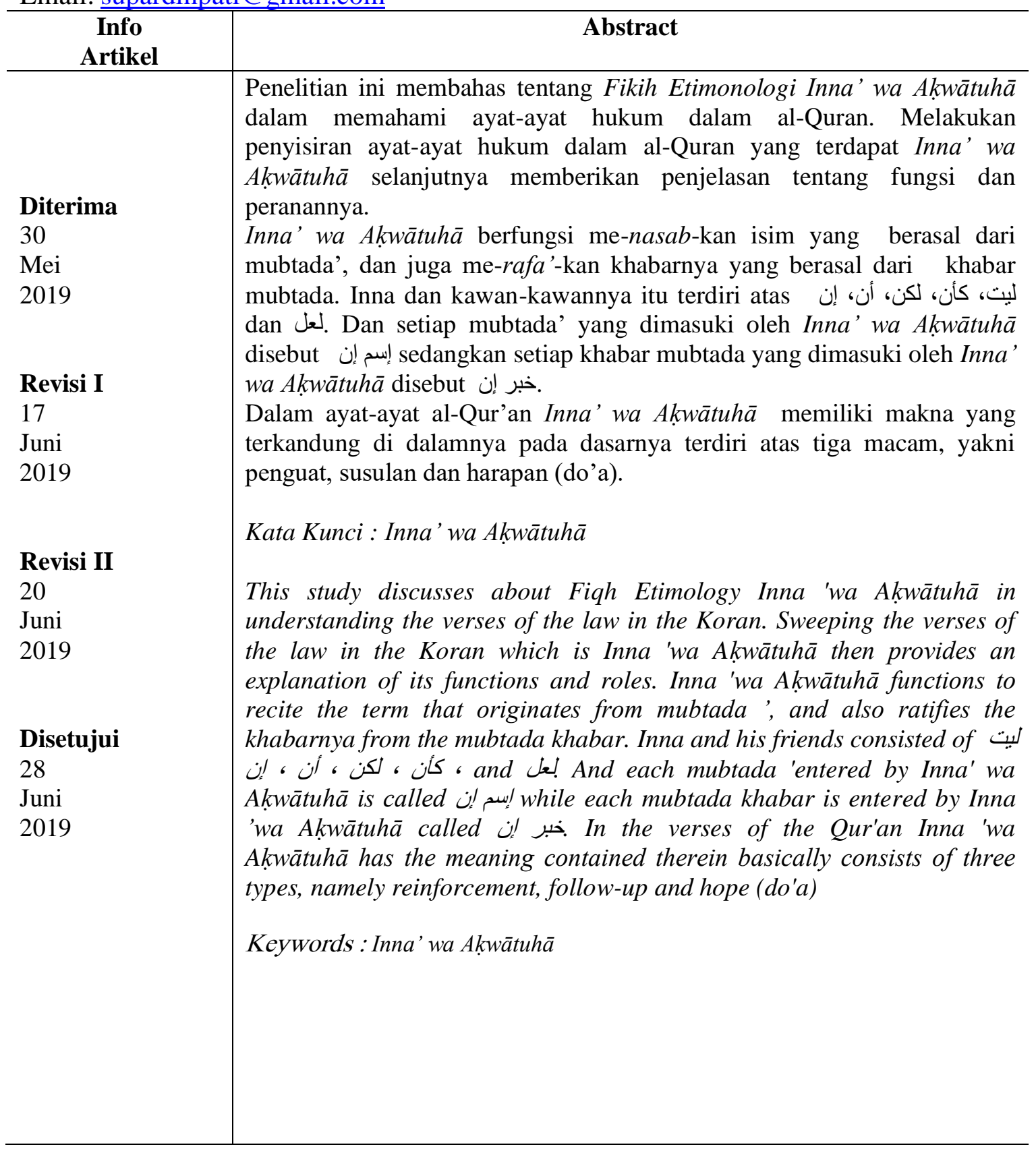


Supardin

\section{A. PENDAHULUAN}

Belajar bahasa Arab sama dengan belajar mendalami kandungan al-Quran yang berarti mengkaji ilmu Islam. Ilmu-ilmu pada masa keemasan Islam digolongkan menjadi empat macam, yaitu ilmu bahasa Arab, ilmu syari'at, sejarah, serta al-hikmah dan filsafat (ilmu-ilmu selain bahasa dan agama). Keempat ilmu tersebut, bahasa Arab merupakan ilmu pertama dipelajari karena bangsa Arab sangat fanatik terhadap bangsa dan bahasanya. Salah satu syarat untuk menjadi pemimpin di kalangan bangsa Arab, baik ia pemimpin politik, pemimpin perang maupun pemimpin sosial kemasyarakatan adalah harus memiliki bahasa yang fasih, murni, dan bermutu.

Ilmu bahasa Arab terdapat beberapa macam ilmu, di antaranya ilmu nahwu, ilmu saraf, balagah, ilmu bahasa, dan ilmu 'arud. Ilmu nahwu dan saraf mula-mula disusun oleh Abul Aswad al-Duali atas nasehat Ali bin Abi Thalib. Sesudah itu menyusul ilmu balagah yang mencakup ilmu bayān, ma'ani, dan badi' yang berfungsi menjelaskan keistimewaan dan keindahan susunan bahasa al-Quran. Dengan adanya ilmu ini muncullah seorang ahli balagah yang termasyhur yaitu Abdul Kadir al-Jurjani. Kemudian untuk memelihara pengertian kata-kata dalam al-Quran, mereka menyusun kamus bahasa Arab yang diprakarsai oleh al-Khaili. Al-Khaili mengumpulkan kata-kata bahasa Arab yang disusun berdasarkan huruf-huruf yang dimulai dengan huruf $\varepsilon$ ('ain) maka diberi nama "Kitäbul Ain". Dan kemudian menyusul kamus yang tersusun menurut huruf hijaiyah oleh Abu Bakar bin Duraid yang dinamakan kamus "alJamhara". Dengan perkembangan bahasa Arab yang pesat lahirlah kitab-kitab dan buku-buku bahasa Arab termasuk Mujam Qawāîd al-Lugah al-Arabiyah yang dikarang oleh Dr. George M. Abdulmassih.

Dalam kitab Mujam Qawāid al-Lugah al-Arabiyah ini dijumpai pembahasan إن

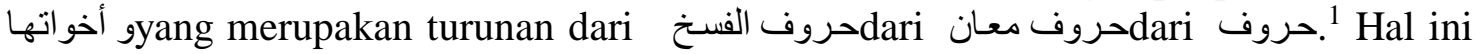
merupakan pembahasan dalam kategori huruf, bukan kata atau kalimat. Akan tetapi إن و mempengaruhi kata atau kalimat sesudahnya.

Berdasarkan penalaran dan pengamatan, penulis menganggap perlu adanya pemahaman yang mendalam tentang asal usul kata إن و أخواتها terutama korelasinya dalam memahami ayat-ayat al-Quran sehingga penulis merumuskan Fikih Etimologi

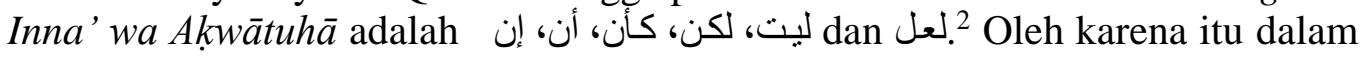
penelitian ini yang dibahas adalah bagaimana Fikih Etimologi Inna' wa Aḳwātuhā dalam memahai ayat-ayat hukum.

\section{B. METODE PENELITIAN}

Metode penelitian yang digunakan adalah penelitian bahasa yang akan mengurai tentang Inna' wa Akwātuhā. Pengumpulan data dengan melakukan penyisiran ayat-ayat al-Quran yang terdapat Inna' wa Akwātuhā selanjutnya memberikan penjelasan tentang fungsi dan peranan Inna' wa Akwātuhā untuk memahami ayat-ayat hukum yang terdapat dalam al-Quran.

\footnotetext{
${ }^{1}$ Jurji Mitri 'Abdu al-Masih, Mu'jam Qawa'id al-Lugah al- 'Arabiyah (Cet. IV; Beirut: Maktabah Libnan, 1989), h. 26.

${ }^{2}$ Irbabullubab dan Djafar Amir, Nahwu dan Saraf (Semarang: Sinar Baru, 1989), h. 67.
} 


\section{PEMBAHASAN}

Untuk memahami suatu disiplin ilmu dengan baik pasti memerlukan pembelajaran dan pemahaman yang mendalam serta komprehensip sebagaimana definisi fikih yaitu pemahaman yang mendalam. Adapun etimologi yang peneliti maksud ialah asal usul kata dari Inna' wa Akhätuhä dalam memahami ayat-ayat hukum, sehingga fikih etimologi yang dimaksud ialah memahami secara mendalam dan lebih luas tentang asal usul kata Inna' wa Akhātuhā serta korelasinya.

Dalam mempelajari bahasa Arab, maka alat yang paling penting digunakan adalah ilmu saraf, الصرف أم العلوم والنحو أبوهـilmu saraf induk segala ilmu, dan ilmu nahwu bapaknya. ${ }^{3}$

Ilmu saraf dikatakan sebagai induk segala ilmu, karena ia melahirkan bentuk kalimat, dan kalimat itu menunjukkan bermacam-macam ilmu. Alasan lain, kalau tidak ada lafaz/kalimat pasti tidak akan ada tulisan, dan tanpa tulisan, sukar mendapatkan ilmu/pengetahuan. Kemudian ilmu nahwu disebut bapak ilmu, karena ia menyelesaikan setiap kalimat dalam susunannya, i'rabnya, bentuk dan semacamnya.

\section{Pengertian, makna dan macam-macamnya}

Yang dimaksudkan inna dan kawan-kawannya ialah (أخوات إهى):

1. للتوكيد dan أن disebut

2. كأن للتشبيه disebut كن أن ان

3. للاستدر الك disebut لكن dist

4. للارجاء لعن لعن disebut

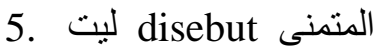

6. لا للنفى

Inna dan kawan-kawannya berjumlah 7 (tujuh), ditambah ada $\vee$ (la). Dan dalam

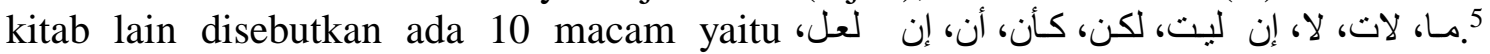
Sedangkan yang umum dikenal hanya enam macam seperti yang disebutkan

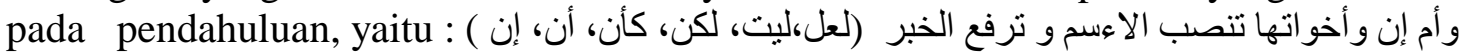
"Inna dan kawan-kawannya/turunannya beramal me-nasab-kan isimnya dan me-rafa'kan khabarnya." "Maksudnya adalah fungsi me-nasab-kan isimnya yang berasal dari mubtada', dan me-rafa'-kan khabarnya yang berasal dari khabar mubtada', (bukan mubtada khabar). Isim inna adalah setiap mubtada yang dimasuki oleh إن atau salah satu kawannya. ${ }^{7}$ Dan khabar inna adalah setiap khabar mubtada yang dimasuki oleh inna dan atau salah satu kawannya. ${ }^{8}$ Inna bersama kawan-kawannya/turunannya, ia menasab-kan isimnya yang semula mubtada dan me-rafa'-kan khabarnya yang semula marfu' oleh mubtada. Jadi huruf inna dalam setiap kalimat adalah mempunyai kedudukan yang penting, karena ia huruf taukid yang artinya penguat, penegas pada suatu kalimat. Maka إن dan adalah sama-sama yaitu taukid yang juga dapat diartikan mengukuhkan pembicaraan seseorang. ${ }^{9}$

${ }^{3}$ Moch. Anwar, Ilmu Saraf (Cet. IV; Bandung: Sinar Baru, 1989), h. iii.

${ }^{4}$ Fu'ad Ni'mah, Mulakhas Qawa'id al-Lugah al'Arabiyah (Cet. V; Kairo: al-Maktabah al-Ilmi, t.t.), h. 27.

${ }^{5}$ Jurji Mitri ‘Abdu al-Masih, Mu’jam Qawa'id al-Lugah al- 'Arabiyah, h. 26.

${ }^{6}$ Moch. Anwar, Ilmu Saraf, h. 96.

${ }^{7}$ Fu'ad Ni'mah, Mulakhas Qawa'id al-Lugah al'Arabiyah, h. 42.

${ }^{8}$ Fu'ad Ni'mah, Mulakhas Qawa'id al-Lugah al'Arabiyah, h. 27.

${ }^{9}$ Moch. Anwar, Ilmu Saraf, h. 96 
Supardin

Sebagai contoh dalam pembukaan UUD 1945 alinea pertama, "sesungguhnya kemerdekaan itu ialah hak segala bangsa...". Jadi kalimat dalam pembukaan itu pada dasarnya diawali dengan huruf inna (إن).

Huruf كن ialah bermakna istidrak (susulan), yakni menyusul perkataan seseorang yang lalu dengan perkataan yang ada di belakangnya. ${ }^{10}$ Sebagai contoh:

جاء القوم ولكن زيدا متأخر

(Kaum itu telah datang, tetapi Zaid belakang).

Huruf لكن seperti mengangkat sesuatu lalu membantingnya dan atau sebaliknya, yakni menjelek-jelekkan seseorang kemudian menyanjungnya. Artinya mengambil sesuatu secara tidak utuh.

Huruf كأن bermakna tasybih (penyerupa), ${ }^{11}$ menyerupakan sesuatu yang lebih baik. Sebagai contoh كأن زيدا قمر (Zaid itu bagaikan bulan). Hal ini memberi perumpamaan sesuatu yang lebih menyenangkan dan atau sebaliknya.

Huruf ليت bermakna tamanni, yakni mengharapkan sesuatu yang mustahil berhasil yang juga bermakna mudah-mudahan. ${ }^{12}$ Tetapi titik berat atau penegasan pada huruf ini ialah mengandai-andai sesuatu yang sangat sukar untuk dilakukan (sukar terealisasi). Contohnya :

ليت الثباب يعود يوما

(Seandainya masa muda dapat kembali pada suatu hari saja).

Huruf لعل bermakna tarajji dan tawaqqu'. Tarajji ialah mengharapkan sesuatu yang baik dan memungkinkan akan berhasil. Tawaqqu ialah hanya dipakai untuk halhal yang menyangkut yang tidak disukai. ${ }^{13}$ Huruf لعل ini adalah bermakna ganda yakni mengharapkan sesuatu yang disukai dan menghindarkan diri dari hal-hal yang buruk. Contoh tarajji لعل الحبيب قاد هل (mudah-mudahan kekasih itu datang), dan contoh tawaqqu لعل العدو هالك (semoga musuh itu binasa). Makna لعلك ini seakan-akan berlawanan arah, sebab yang satu menghendaki kebaikan, sedangkan yang lain menginginkan terhindar dari kejelekan. Namun demikian ia solid dalam harapan dan keinginan yang lebih menguntungkan.

\section{Contoh-contoh Inna' wa $A \boldsymbol{k} w \bar{a} t u h \bar{a}$ dalam al-Qur'an}

Telah dikemukakan bahwa inna dan kawan-kawanya yang dimaksudkan adalah إن و أخواتها Dan contoh-contoh yang dikemukakan adalah ـ لعل dan ليت، كأن، لكن، أن، إن dalam al-Qur'an yang tidak bersambung dengan damir atau huruf lain. Dan kemudian masing-masing dikemukakan dua contoh kecuali كأن yang satu contoh.

\section{1. (inna)}

Huruf إن (yang berdiri sendiri) dalam al-Quran paling banyak dijumpai dalam jumlah 608 kali disebutkan di berbagai surah dalam ayat-ayat al-Quran, ${ }^{14}$ di antaranya:

1) Q.S. al-Ankabūt/29: 45:

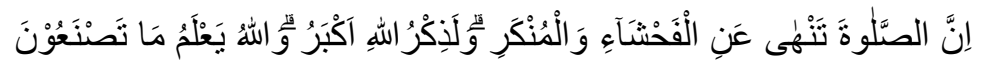

\footnotetext{
${ }^{10}$ Moch. Anwar, Ilmu Saraf . h. 96

${ }^{11}$ Sayyid Ahmad Zaini Dahlan, Mukhtarar Jiddan, h. 150

${ }^{12}$ ayyid Ahmad Zaini Dahlan, Mukhtarar Jiddan.

${ }^{13}$ Moch. Anwar, Ilmu Saraf, h. 97.

${ }^{14}$ CD-Holy al-Qur'an ( صخر ; Komputer: Vers, 6,50
} 
Terjemahnya:

Sesungguhnya salat itu mencegah dari (perbuatan) keji dan mungkar. Dan (ketahuilah) mengingat Allah (salat) itu lebih besar (keutamaannya dari ibadah yang lain). Allah mengetahui apa yang kamu kerjakan. ${ }^{15}$

Ayat di atas dalam memahami bahwa fungsi inna' sebagai bentuk penegasan bahwa sesunggunya salat itu mencegah dari perbuatan keji dan mungkar di dalamnya menjelaskan maslahat terhadap individu dan masyarakat yang menjadi penguatan syariat Islam.

2) Surah an-Nisā/4: 58:

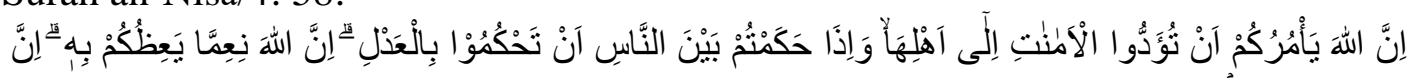

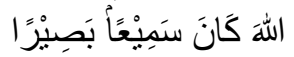

Terjemahan:

Sungguh, Allah menyuruhmu menyampaikan amanat kepada yang berhak menerimanya, dan apabila kamu menetapkan hukum di antara manusia hendaknya kamu menetapkannya dengan adil. Sungguh, Allah sebaik-baik yang memberi pengajaran kepadamu. Sungguh, Allah Maha Mendengar, Maha Melihat. ${ }^{16}$

Inna' dalam ayat ini menegaskan tentang al-Quran mengajarkan suatu tuntunan hidup yakni tentang amanah. Perintah menyampaikan amanat secara sempurna dan tepat waktu kepada yang berhak menerimanya, menetapkan hukum di antara manusia yang berselisih hendaknya diselesaikan dengan adil. Perintah memegang teguh amanah serta berlaku adil adalah sebaik-baik pengajaran. Dengan hadirnya isim inna dan khabar inna, maka ayat-ayat tersebut bermakna taukid yakni menguatkan, menegaskan dan mengukuhkan.

\section{2. أن (anna)}

Huruf أن (yang berdiri sendiri) ditemukan dalam al-Qur'an sebanyak 98 kali, ${ }^{17}$ di antaranya ayat yang disebutkan adalah:

1) Q.S. al-Baqarah/2: 25:

Terjemahnya:

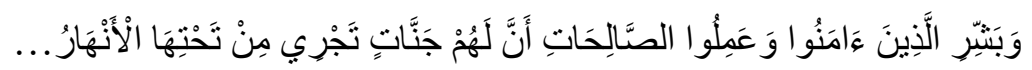

Dan sampaikanlah berita gembira kepada mereka yang beriman dan berbuat baik, bahwa bagi mereka disediakan surga-surga yang mengalir sungaisungai di dalamnya... ${ }^{18}$

2) Q.S. al-Baqarah/2: 77:

Terjemahnya:

$$
\text { أَوَلَا بَعْلَمُونَ أَنَّ اللَّهَ يَعْلَمُ مَا يُبِِرُونَ وَمَا يُعْلْنُونَ }
$$

Tidaklah mereka mengetahui bahwa Allah mengetahui segala yang mereka sembunyikan dan segala yang mereka nyatakan. ${ }^{19}$

\footnotetext{
${ }^{15}$ Kementerian Agama, Al-Quran dan Terjemahnya (Jakarta: PT. Adhi Aksara Abadi, 2011), h.
} 562.

\footnotetext{
${ }^{16}$ Kementerian Agama, Al-Quran dan Terjemahnya, h. 113

${ }^{17}$ CD-Holy al-Qur'an ( صخر ; Komputer: Vers, 6,50.

${ }^{18}$ Kementerian Agama, Al-Quran dan Terjemahnya, h. 5
} 
Supardin

Ayat tersebut menegaskan bahwa Allah mengetahui segala yang nyata dan tersembunyi terhadap apa yang dilakukan oleh manusia (ayat ini bermakna penguat/taukid).

\section{3. لكن (lakinna)}

Huruf لكن (yang berdiri sendiri) ditemukan dalam al-Qur'an sebanyak enam kali. ${ }^{20}$ Dua dari ayat tersebut adalah:

1) Surah āli ‘Imrān/3: 198:

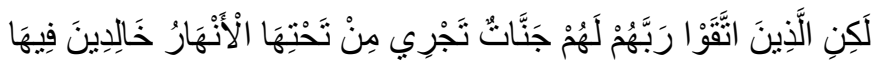

Terjemahnya:

Akan tetapi orang-orang yang bertaqwa kepada Tuhannya, bagi mereka surga yang mengalir sungai-sungai di dalamnya... ${ }^{21}$

Ayat ini merupakan anak kalimat sebagai susulan dari kalimat sebelumnya tentang tempat orang-orang yang kafir dalam neraka jahannam (istidrak pada kata sebelumnya).

2) Q.S. al-Nisā/4: 162:

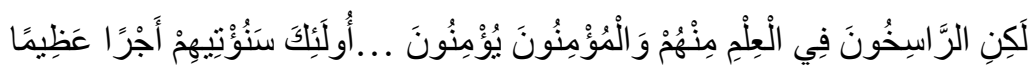

Terjemahnya:

Tetapi orang-orang yang mendalami ilmunya di antara mereka dan orangorang mu'min, ...Orang-orang itulah yang akan Kami berikan kepada mereka pahala yang besar. ${ }^{22}$

Ayat ini merupakan anak kalimat sebagai susulan dari kalimat sebelumnya yang menerangkan tentang siksaan bagi orang-orang kafir yang senantiasa memakan riba, dan pahala bagi orang-orang yang beriman dan mengerjakan amal saleh (ayat ini bermakna istidrak).

\section{4. كأن (kaanna)}

كuruf كأن (yang berdiri sendiri) dalam al-Qur'an hanya satu kali, ${ }^{23}$ yakni terdapaat pada Q.S. Lukmān/31: 7:

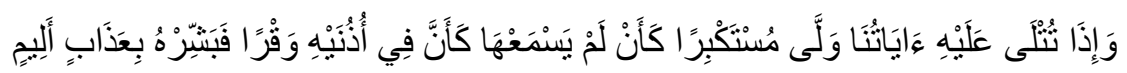

Terjemahnya:

Dan apabila dibacakan kepadanya ayat-ayat Kami dia berpaling dengan menyombongkan diri seolah-olah dia belum mendengarnya, seakan-akan ada sumbat di kedua telinganya; maka beri kabar gembiralah dia dengan azab yang pedih. ${ }^{24}$

Huruf كأن dalam ayat ini berfungsi tasybih yakni menyerupakan atau perumpamaan, sehingga bermakna seakan-akan ada yang menyumbat telinga bagi

\footnotetext{
${ }^{19}$ Kementerian Agama, Al-Quran dan Terjemahnya, h. 15

${ }^{20} \mathrm{CD}$-Holy al-Qur'an ( صخر ; Komputer: Vers, 6,50.

${ }^{21}$ Kementerian Agama, Al-Quran dan Terjemahnya, h. 97

${ }^{22}$ Kementerian Agama, Al-Quran dan Terjemahnya, h. 136.

${ }^{23}$ CD-Holy al-Qur'an ( صخر ; Komputer: Vers, 6,50).

${ }^{24}$ Kementerian Agama, Al-Quran dan Terjemahnya, h. 580
} 
orang-orang yang mempergunakan perkataan yang tidak berfaidah untuk menyesatkan manusia.

\section{5. ليت (laita)}

Huruf ليت (yang berdiri sendiri) terdapat dalam al-Qur'an hanya tiga kali, ${ }^{25}$ di antaranya pada:

1) Q.S. al-Qașaș/28:79:

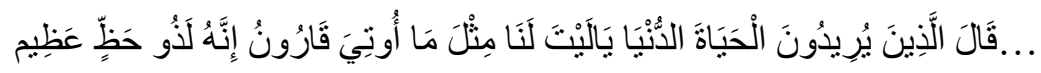

Terjemahnya:

Berkatalah orang-orang yang menghendaki kehidupan dunia: "Moga-moga kiranya kita mempunyai seperti apa yang telah diberikan kepada Karun; sesungguhnya ia benar-benar mempunyai keberuntungan yang besar". ${ }^{26}$

Ayat ini mengandung makna harapan atau do'a semoga mendapat keberuntungan sebagaimana telah diberikan kepada Qarun

2) Surah Yāsīn/36: 26:

$$
\text { قِيلَ ادْخُلِ الْجَنَّةَ قَالَ بَالَيْتَ فَوِْْي يَعْلَمُونَ }
$$

Terjemahnya:

Dikatakan (kepadanya): "Masuklah ke surga". Ia berkata: "Alangkah baiknya sekiranya kaumku mengetahui". ${ }^{27}$

Ayat ini juga mengandung harapan (do'a) yang lebih baik lagi, yakni memohon pengampun Allah.

\section{6. لعل (la'alla)}

Huruf لعل (berdiri sendiri) dalam al-Qur'an juga ditemukan hanya tiga kali, ${ }^{28}$ di antaranya terdapat pada:

1) Q.S. al-Aḥzāb/33: 63:

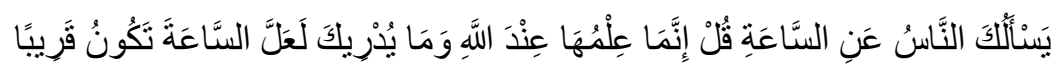

Terjemahnya:

Manusia bertanya kepadamu tentang hari berbangkit. Katakanlah: "Sesungguhnya pengetahuan tentang hari berbangkit itu hanya di sisi Allah". Dan tahukah kamu (hai Muhammad), boleh jadi hari berbangkit itu sudah dekat waktunya. $^{29}$

2) Q.S. asy-Syūrā/42:17:

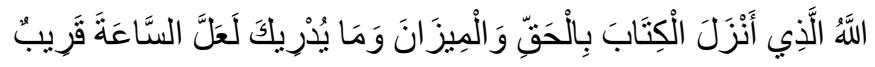

\footnotetext{
${ }^{25}$ CD-Holy al-Qur'an ( صخر ; Komputer: Vers, 6,50).

${ }^{26}$ Kementerian Agama, Al-Quran dan Terjemahnya, h. 556

${ }^{27}$ Kementerian Agama, Al-Quran dan Terjemahnya, h. 627

${ }^{28}$ CD-Holy al-Qur'an ( صخر ; Komputer: Vers, 6,50).

${ }^{29}$ Kementerian Agama, Al-Quran dan Terjemahnya, h. 603.
} 
Supardin

Terjemahnya:

Allah-lah yang menurunkan kitab dengan (membawa) kebenaran dan (menurunkan) neraca (keadilan). Dan tahukah kamu, boleh jadi hari kiamat itu (sudah) dekat. ${ }^{30}$

Kedua ayat tersebut mengandung makna tarajji yang berarti boleh jadi (kemungkinan) akan terjadi dalam waktu yang tidak terlalu lama.

Inna' wa Akwātuhā dalam ayat-ayat al-Qur'an memberikan pemahaman dalam memahami ayat-ayat hukum serta berfungsi sebagai penekanan, pengharapan, penguatan dalam penetapan hukum

\section{PENUTUP}

Inna dan kawan-kawannya/turunannya adalah berfungsi me-nasab-kan isimnya yang berasal dari mubtada', dan juga me-rafa'-kan khabarnya yang berasal dari

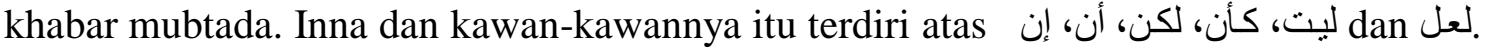
Dan setiap mubtada' yang dimasuki oleh inna' wa Akwātuhā disebut إنس إن , sedangkan setiap khabar mubtada yang dimasuki oleh inna' wa Aḳwātuhā disebut خبر إن. Makna yang terkandung di dalamnya pada dasarnya terdiri atas tiga macam, yakni penguat, susulan dan harapan (do'a).

\section{DAFTAR PUSTAKA}

Anwar, Moch. Ilmu Saraf. Cet. IV; Bandung: Sinar Baru, 1989.

Al-Baqi, Muhammad Fu'ad 'Abdul. Al-Mu'jam al-Mufahras li al-Faz al-Qur'an alKarim. Beirut: Dar al-Fikr, 1987 M.- 1407 H.

CD-Holy al-Qur'an. Sakhar: Komputer: Ver; 6,50

Dahlan, SayyidAhmad Zaini. Mukhtasar Jiddan. Diterjemahkan oleh Chotibul Umam dengan judul "Pedoman Dasar Ilmu Nahwu", Cet. V; Jakarta: Darul Ulum Press, 1992.

Halilulrohman, Panduan Membaca dan Memahami Kitab Kuning. Bandung: CV. Armico, 2012.

Hermawan, Acep. Metodologi Pembelajaran Bahasa Arab. Cet. IV; Bandung: Remaja Rosda Karya, 2014.

Kementerian Agama, Al-Quran dan Terjemahnya. Jakarta: PT. Adhi Aksara Abadi, 2011.

Ni'ma, Fu'ad Mulkhas. Qawa'id al-Lugah al-'Arabiyah. Cet. IV; Beirut: Maktabah Libnan, 1989.

Yunus, Mahmud. Kamus Arab Indonesia. Jakarta: PT. Hidaya Karya Agung, 1989.

\footnotetext{
${ }^{30}$ Kementerian Agama, Al-Quran dan Terjemahnya, h. 695-696.
} 